3. Постанова Кабінету Міністрів № 585 «Про встановлення строку навчання у загальноосвітніх навчальних закладах для дітей з особливими освітніми потребами». Законодавство України. URL: http://zakon.rada.gov.ua/laws/show/585-2003$\% \mathrm{D} 0 \% \mathrm{BF}$ (дата звернення: 15.09.2018).

\title{
References:
}

1. Salamankskaia dieklaratsia i ramki dieistvii po obrazovaniiu lits s osobymi potriebnostiami [The Salamanca Statement and Framework for Action on Special Needs Education]. YuNESKO. URL: http://www.un.org/ru/documents/decl_conv/ declarations/ pdf/salamanka.pdf (data zvernennia 7.08.2018).

2. Postanova Kabinetu Ministriv Ukrainy № 780 «Pro vnesennia zmin do postanovy vid 23 kvitnia 2003 r. № 585» [Decree by the Cabinet of Ministers of Ukraine № 780 "On introducing changes to Decree № 585 issued on April, 23, 2003"]. Zakonodavstvo Ukrainy. URL: https://zakon.rada.gov.ua/laws/show/780-2010-\%D0\%BF (data zvernennia 16.09.2018).

3. Postanova Kabinetu Ministriv Ukrainy № 585 "Pro vstanovlennia stroku navchannia u zagalnoosvitnikh zakladakh dlia ditei z osoblyvymy osvitnimy potrebamy" [Decree by the Cabinet of Ministers of Ukraine № 585 "On setting the term of learning in comprehensive educational institutions for children with special educational needs"]. Zakonodavstvo Ukrainy. URL: http://zakon. rada.gov.ua/ laws/show/585-2003-\%D0\%BF (data zvernennia 15.09.2018).

\section{Shcherba N. S. The practice-oriented teaching foreign language senior learners with cerebral palsy: implementation possibilities}

According to international human rights documents (and namely of Salamanca Statement and Framework for Action on Special Needs Education), children with special educational needs and disabilities (SEND) have a right to be enrolled into mainstream schools if they have no special contraindications. The latter can comprise, among others, blindness, deafness and complex impairments, especially combined with intellectual disorders. Meeting the requirement of organizing the inclusive learning for children with severe forms of disability presupposes taking into consideration all the diversity of their individual peculiarities. In case of teaching foreign language senior learners with such complex impairments as cerebral palsy a teacher should be able to use a set of tools that would enable the analysis of these individual differences, including: physical, sensory and cognitive possibilities, learning difficulties and disabilities, restrictions, intelligences, cognitive styles, learning and professional interests.

But the existing system of would-be teachers 'professional preparation is only developing today, as only several higher educational institutions have relevant courses. Besides the scientific literature analysis has revealed the absence of correspondent sources to consult with. This discrepancy proves the topicality of the topic chosen.

The article contains 2 questionnaires - for palsied senior learners and their parents - and an express-dossier to systematize obtained data on learner's ability to: independently walk, stand, sit, talk, write, read, hear, do self-service; on learning disabilities, SEN, cognitive abilities, learning interests, strengths and professional prospects and options, if there are and they are chosen. All these tools were designed, experimentally approbated and improved by the article's author. The data obtained and systematized empowers a teacher to: implement differentiated, individualized and practice-oriented instruction, to organize additional correction and the monitoring of learner's progress in the Individual program of child's development and in his Individual plan.

Key words: cerebral palsy, inclusive learning, foreign language, questionnaire, express-dossier.

\author{
УДК [378.016.80]:33 \\ DOI https://doi.org/10.31392/2311-5491/2019-69.68
}

Якубовська М. С.

\section{ДОСВІД НАУКОВОЇ ШКОЛИ АКАДЕМІКА Н. Г. НИЧКАЛО В СИСТЕМІ ВИЩОЇ ПРОФЕСІЙНОЇ ШКОЛИ СУЧАСНОСТІ: КУЛЬТУРОЛОГІЧНИЙ АСПЕКТ}

На прикладі концептуального вивчення творчого наукового діалогу акад. Н. Г. Ничкало в системі інноваційних засад наукової діяльності дійсного члена НАПН України, доктора педагогічних наук, професора В. О. Радкевич розглядається впровадження культурологічних засад наукової школи «педагогіки життя» акад. Н. Г. Ничкало в системі досягнень сучасної професійної школи. Для досягнення мети були реалізовані такі завдання: охарактеризовано концептуальні культурологічні принципи інноваційних освітніх технологій навчання та викладання в системі сучасної професійної школи; на прикладі досягнень педагогічної школи акад. Н. Г. Ничкало проаналізовано роль культурологічних засад у системі інноваційних освітніх технологій вищої професійної школи. Методологія дослідження полягає в застосуванні компаративного, історико-логічного, синергетичного методів. Зазначений методологічний підхід дозволяє проаналізувати системне творення архетипної моделі дослідження наукової школи акад. Н. Г. Ничкало як иілісної функиіональної єдності професійної школи тасоиіуму. Наукова новизна роботи полягає у розгляді науково-педагогічних засад зв'язку культурологічного світогляду людини з гармонійним розвитком соиіального буття, щзо є основою культурологічного простору духовної свободи та творчості особистості. На прикладі концептуального вивчення впровадження досвіду акад. Н. Г. Ничкало в систему інновачійних засад наукової діяльності дійсного члена НАПН України, доктора педагогічних наук, професора В. О. Радкевич розглядається розвиток наукової школи «педагогіки життя» акад. Н. Г. Ничкало в системі досягнень сучасної професійної освіти. 
За концептуальними засадами науково-педагогічної иколи акад. Н. Г. Ничкало, система вищої професійної освіти ключовий чинник успіху розвитку країни. На відміну від попередніх десятиліть, коли економічне зростання відбувалося шляхом експлуатації природних і виробничих ресурсів, сучасна економічна політика зосереджена на проблематиці розвитку потенціалу й продуктивного впливу людського капіталу на ефективність виробництва.

Ключові слова: культурологічна компетентність, культурологічний світогляд, педагогічний дискурс, компетентнісний, особистісно-діяльнісний, культурологічний та аксіологічний методи, культурологічна компетентність, професійна освіта, культурологічне середовище.

Сучасна професійна освіта перебуває в системі постійного самооновлення: у час інноваційного осмислення новітніх шляхів духовного поступу людства, коли відбувається перехід від творення нової культурологічної парадигми епохи до пошуків шляхів модерної реалізації даної культурологічної парадигми.

Спрямування освіти України в Свропейський освітній простір поряд із вимогами до професійної готовності випускника вищої професійної освіти вимагає багатогранного, культурологічно спрямованого підходу до розроблення інноваційних освітніх моделей, творення культурологічно спрямованих навчальних програм, навчально-методичного забезпечення для культурологічної підготовки студентів технічних університетів.

Останні дослідження, присвячені культурологічній основі інноваційних освітніх технологій навчання та викладання, зосереджуються на культурологічному алгоритмі становлення та розвитку освітніх технологій.

Вивчення впроваджень педагогічного досвіду наукової школи акад. Н.Г. Ничкало у творчій діяльності вихованців даної школи ще не стало предметом грунтовних наукових досліджень. Під час дослідження було використано наукові засади, які стали теоретичною основою дослідження. Дані наукові дослідження можна охарактеризувати за такими науковими напрямками: визначальна роль вищої професійної освіти у стратегії духовно-екзистенційної боротьби за оновлення суспільства (Кремінь В. Г., Зязюн І. А., Гончаренко С. У.), парадигма неперервної професійної освіти у системі сучасного соціуму (Андрущенко В. П., Огнев’юк В. О., Сисоєва С. О., Ягупов В. В.), організація навчального процесу у вищих навчальних закладах (Базиль О. О., Герлянд Т. М., Герганов Л. Д., Сршова Л. М., Каленський А. А., Лузан П. Г. Пригодій Л. А., Орлов В. Ф., Пуховська Л. П., Радкевич В. О., Романишина Л. М., Теловата М. Т., Щербак О. І.); наукова педагогічна термінологія професійної освіти і навчання в країнах Європейського Союзу (Пуховська Л. П., Леу С. О., Радкевич О. П., Шимановський М. М., Бородієнко О. В.); професійний розвиток та саморозвиток студентів, упровадження інноваційних технологій у системі вищої професійної школи, формування педагогічної культури майбутнього викладача вищого навчального закладу (Євтух М. Б., Сршова Л. М., Каленський А. А., Лузан П. Г., Пантюк М. П., Пригодій Л. А., Орлов В. Ф., Пуховська Л. П., Радкевич В. О., Романишина Л. М., Теловата М. Т.)

Інноваційна парадигма сучасної професійної освіти здатна прискорити ефективність і дієвість як економічних, так і суспільно-політичних реформ. На початку XX століття в українській педагогіці утвердилася ціла низка наукових педагогічних шкіл, які розглядають формування професійної компетентності студентів як важливу складову частину системи нинішньої професійної освіти, як один із провідних принципів реалізації інноваційних процесів у професійній освіті, а отже, і в суспільстві.

За концептуальними засадами науково-педагогічної школи акад. Н. Г. Ничкало, система вищої професійної освіти - ключовий чинник успіху розвитку країни. На відміну від попередніх десятиліть, коли економічне зростання відбувалося шляхом експлуатації природних і виробничих ресурсів, сучасна економічна політика зосереджена на проблематиці розвитку потенціалу й продуктивного впливу людського капіталу на ефективність виробництва. За наявності талановитих та кваліфікованих кадрів розвиток країни буде успішним та стабільним.

Н. Г. Ничкало, досліджуючи проблему неперервної освіти у системі світового досвіду, наголошує на необхідності поєднання інтелектуального розвитку студента з основами культурологічного, емоційно-вольового, ефективно-розвивального становлення у системі постійного безперервного розвитку. У системі сучасної професійної освіти важливим є сформована воля студента до постійного навчання. Духовно-практична атмосфера педагогічних процесів займає важливе місце у формуванні необхідності вольових зусиль студентів.

Продовження традицій наукової школи акад. Н. Г. Ничкало знаходить втілення у творчій діяльності багатьох учених сучасності, серед яких творча особистість дійсного члена НАПН України, доктора педагогічних наук, професора В. О. Радкевич займає важливе значення.

Система педагогічних інновацій двох видатних учених творить інноваційну парадигму інноваційного культурологічного мислення в системі вищої професійної освіти.

Упродовж останнього десятиліття в сучасній вітчизняній педагогіці активно розробляється та впроваджується багатогранне коло культурологічних проблем, пов'язаних з якісно новим етапом розвитку сучасного суспільства, величезного значення набувають наукові праці українських педагогів, які досліджують проблему безперервної освіти. Дана проблема має широке значення. Соціальне - оскільки виробництво зазнає постійних змін, та виникає потреба постійної його модернізації. Культурологічно-особистісне - людська природа вимагає постійної роботи над удосконаленням своїх компетентностей.

У межах функціонування безперервного розвитку досліджується система формування і впровадження в життя культурологічних ідей та твориться методика їхнього постійного оновлення та вдосконалення, 
оскільки культура як явище є постійно змінним процесом і потребує постійної присутності людини для свого системного відтворення у навколишньому світі.

У рамках даного інноваційного наукового напряму народилася ідея якісно нової парадигми в сучасній педагогіці - культурологічної, яка виступає найперше за системне формування освітнього процесу як творчого явища, ламає усталені стереотипи.

Навчальний процес виходить за межі замкнутої системи і сам стає основою творення нової культурологічної парадигми сучасності. Присутність постійного творчого підходу в системі творення власних думок і стилю поведінки - це можливість пізнавати світ і використовувати його і для формування власного «я», і для професійної діяльності. Навчальний процес стає джерелом культурологічної синенергетичної сили, здатної творити новий інноваційний світ сучасного буття.

У працях акад. В. О. Радкевич на практичній основі розглядаються культурологічні засади формування творчої особистості сучасного фахівця. Інтегративним і наскрізним для формування культурологічних особливостей, які сприятимуть ефективному розвитку професійних компетентностей людини, які ведуть до максимального розкриття індивідуальних якостей кожного індивіда.

Мистецтво педагогічної взаємодії, за концептуальними засадами акад. Н. Г. Ничкало, впроваджуваними у розробках акад. В.О. Радкевич, допомагають вибрати найбільш оптимальні та результативні способи використання синенергетичних сил студента як під час навчання, так і під час виробничої діяльності.

Розвиваючись у конкретному виді діяльності, індивід спирається на досвід попередніх поколінь. Структуруючи свою діяльність, він формує мету, смисли, мотиви своїх устремлінь на основі особистого та соціального досвіду. Засвоєні схеми, структури і механізми діяльності індивіда будуть діяльними за умови творчого підходу до їхньої реалізації. Життєва повнота, яскравість індивідуального підходу в педагогічних процесах, відчутність самодостатніх рис є показником мистецького підходу до мистецтва педагогічної взаємодії.

У системі особистісного культурологічного становлення формується необхідність людської індивідуальності навчатися впродовж усього життя. Формується потреба охопити всю різноманітність використання культурологічних засобів, де умовність форми найменше обмежує міру і характер художньої конкретизації.

У системі культурологічного підходу до алгоритму творення сучасної педагогічної парадигми освітнього процесу, за концепцією акад. Н. Г. Ничкало, епіцентром освіти є людина як активна творча індивідуальність, яка постійно має здатність до особистісної самодетермінації у процесі спілкування і творчої співпраці у виробничому колективі.

Педагог не має права спрощувати, полегшувати дійсну складність і трудність стосунків та обставин. Величезне значення конкретно-чуттєвого досвіду пояснюється особливостями сприймання та мислення. Погодженість у культурологічному мисленні наступає, коли педагог добивається від свого студента потреби навчатися впродовж усього життя.

Досліджуючи проблему безперервної освіти у системі світового досвіду, доктор педагогічних наук В. О. Радкевич наголошує на необхідності поєднання інтелектуального розвитку студента 3 основами культурологічного, емоційно-вольового, ефективно-розвивального становлення у системі постійного безперервного розвитку.

Педагогічна школа академіка Н. Г. Ничкало заклала основи дослідження сучасного культурологічного простору через алгоритм інтеграції сучасної професійної школи і особистісно зорієнтованої освіти, що знайшло продовження в численних дослідженнях акад. В. О. Радкевич. Інтеграція сучасного життя і системи людиноцентричної педагогіки досліджується через вивчення творення інноваційних мистецько-наукових тенденцій, що є основою дискурсу культурологічної взаємодії законів життя і законів мистецтва, що становить основу гуманітарної безпеки сучасності, складовою частиною якої виступають психологічна та інформаційна безпека сучасного соціуму.

Дискурс взаємодії сучасної культурологічної парадигми із системою педагогічних інноваційних технологій сучасної вищої професійної школи на основі вивчення алгоритмів методологічних, професійнопедагогічних та дидактичних принципів розглянуто в численних наукових дослідженнях акад. В. О. Радкевич. Через систему культурологічного аспекту досліджено взаємодію педагогічного та культурологічного дискурсу як основу формування психологічної та інформаційної безпеки суспільства, розвиток людської індивідуальності в системі людиноцентричної педагогіки, проаналізовано мистецтво взаємодії педагогічних та культурологічних методів у сучасному культурологічному соціумі, без яких не відбувається становлення сучасної професійної школи, котра найбільшим чином реагує на виклики та потреби життя.

Висновок. Інноваційні освітні технології навчання та викладання у вищій професійній школі за системними принципами наукової школи Н. Г. Ничкало забезпечують відповідь на одне 3 найголовніших питань освітнього процесу: яким чином представити, передати нові знання та створити умови для їхнього ефективного засвоєння. Поєднання сучасної культурологічної парадигми із системою педагогічних інноваційних технологій сучасної вищої професійної школи на основі вивчення алгоритмів методологічних, професійно-педагогічних та дидактичних принципів створює ефективні передумови втілення перспективних інноваційних освітніх технологій розвитку, навчання, викладання в сучасній професійній школі. 


\section{Використана література:}

1. Дичківська І. М. Інноваційні педагогічні технології : навчальний. посібник. Київ : Академвидав, 2004. 352 с.

2. Ничкало Н. Г. Професійне навчання дорослого населення: теоретико-методологічні засади ; Національна академія пед. наук України, Інститут педагогічної освіти і освіти дорослих. Київ ; Кіровоград : Імекс, 2013. 263 с.

3. Ничкало Н. Г. Теоретико-методологічні проблеми розвитку досліджень 3 педагогіки і психології професійної освіти. Діалог культур: Україна у світовому контексті : матеріали 1 міжнар. філ.-культ. читань. м. Львів, 25-26 квітня 1996 р. Львів, 1996. С. 3-10.

4. Ничкало Н. Г., Гончаренко С. У., Радкевич В. О. Державні стандарти професійної освіти: теорія і методика. Хмельницький, ТУП, 2002. 334 с.

5. Мистецтво у розвитку особистості / Н.Г. Ничкало та ін. Чернівці : Зелена Буковина, 2006. 224 с.

6. Ничкало Н. Г. Трансформація професійно-технічної освіти в Україні. Київ : Пед. думка, 2008. 199 с.

7. Радкевич В. О. Інтеграція загальнохудожньої та професійної підготовки фахівців художнього профілю. Педагогіка $i$ nсихологія професійної освіти : зб. наук. пр. Львів, 1999. № 1. С. 68-72.

8. Радкевич В. О. Концепція професійно-художньої освіти. Професійно-технічна освіта: наук.-метод. журнал. 2000. № 2. C. 43-47.

9. Радкевич В. О. Роль інноваційних процесів у підготовці майбутніх фахівців. Сучасні інформаційні технології та інноваційні методики навчання в підготовці фахівців: методологія, теорія, досвід, проблеми : зб. наук. пр. ; редкол. І.А. Зязюн та ін. Київ ; Вінниця, 2000. С. 196-200.

\section{References:}

1. Duchkivcka I. M. Innovative pedagogical tehnologies: Manual. - K.: Akademvudav, 2004. - 352 pp.

2. Nichkalo N. G. Professional training of the adult population: theoretical and methodological principles. - National Academy of Pedagogy. Sciences of Ukraine, Institute of Pedagogical Education and Adult Education .- K., Kirovograd: Imex, 2013.- 263 pp.

3. Nichkalo N. G. Theoretical and methodological problems of the development of research on pedagogy and psychology of vocational education / Dialogue of cultures: Ukraine in the global context: materials 1 intern. filth-cult readings Lviv, April 25-26, 1996.- 1996.- P. 3-10.

4. Nichkalo N. G., Goncharenko S. U., Radkevich V. O. State standards for vocational education: theory and methodology. Khmelnitsky, TUP, 2002. - 334 p.

5. Nychkalo N.G., Zyazun IA, Otich O.M., Solomach S.O., Sotskaya G.I., Vovk M.P., Popik O.I., Filipchuk N.O., Chambers MI, Kharchenko P.V., Nikolai N.Yu. Art in the development of personality. - Chernivtsi: Zelena Bukovina, 2006.-224 p.

6. Nichkalo N. G. Transformation of vocational education in Ukraine. - K .: Ped. opinion, 2008. - 199 p.

7. Radkevich V. O. Integration of the general artistic and professional training of specialists in the artistic profile / Valentina Radkevich // Pedagogics and psychology of vocational education: Sb. sciences Ave. - Lviv, 1999. - No. 1.- P. 68-72.

8. Radkevich V. O. The concept of vocational education / Valentyna Radkevich // Vocational and technical education: sciencemethod. magazine. - 2000. - No. 2. - P. 43-47.

9. Radkevich V. O. The role of innovative processes in the training of future specialists / Valentina Radkevich // Modern information technologies and innovative methods in the training of specialists: methodology, theory, experience, problems: Sb. sciences etc. / [red. IA Zyazyun, R.S. Gurevich, N. G. Nichalko .]. - K.; Vinnytsya, 2000. - P. 196-200.

Yakubovska M. S. The experience of the scientific school of academician N. H. Nychkalo in the system of high professional school of the present: cultural aspect

On the example of the conceptual study of the creative scientific dialogue acad. Nichkalo N.G. in the system of innovative foundations of scientific activity of the current member of the National Academy of Sciences of Ukraine, Doctor of Pedagogical Sciences, professor Radkevich V.O. the introduction of cultural principles of the scientific school «Pedagogy of Life» is considered. Acad. Nichkalo N.G. in the system of achievements of the modern vocational school To achieve the goal, the following tasks were realized: the conceptual culturological principles of innovative educational technologies of teaching and teaching in the system of modern professional school are characterized; on the example of the achievements of the pedagogical school acad. Nichkalo N.G. the role of cultural fundamentals in the system of innovative educational technologies of the higher professional school is analyzed. The methodology of the research is to apply comparative, historical-logical, synergetic methods. The above methodological approach allows us to analyze the system creation of an archetype model of the research of a scientific school of acad. Nichkalo N.G. as a holistic functional unity of the vocational school and socialism. The scientific novelty of the work is to consider the scientific and pedagogical foundations of the connection of the cultural worldview of a person with the harmonious development of social life, which is the basis of the cultural space of spiritual freedom and creativity of the individual. On the example of a conceptual study of the introduction of the experience of acad. Nichkalo N.G. in the system of innovative principles of scientific activity of the current member of the National Academy of Sciences of Ukraine, doctor of pedagogical sciences, professor Radkevich V.O. The development of a scientific school «Pedagogy of Life» of the Acad. Nichkalo N. G. in the system of achievements of modern vocational education.

According to the conceptual principles of the scientific and pedagogical school acad. Nychkalo N. G., the system of higher professional education is a key factor in the success of the country's development. Unlike in previous decades, when economic growth was through exploitation of natural and productive resources, modern economic policy focuses on the problem of developing the potential and productive impact of human capital on production efficiency.

Key words: cultural competence, cultural view, pedagogical discourse, competence, personality-activity, cultural and axiological methods, culturological competence, vocational education, culturological environment. 